\title{
URINARY TRACT INFECTION: ETIOLOGY AND ANTIMICROBIAL RESISTANCE WITH REFERENCE TO ADHESIVE ORGANELLES
}

\author{
*Navin Kumar Chaudhary ${ }^{1}$, S Mahadeva Murthy ${ }^{2}$ \\ ${ }^{1}$ Research Scholar, ${ }^{2}$ Associate Professor, Department of Microbiology, Yuvaraja's College (Autonomous), University of Mysore, \\ Mysore, India. \\ *Corresponding author: nununavin@yahoo.co.in Mobile No.00977-9845610052
}

\begin{abstract}
Background: Urinary tract infection (UTI) is a serious health problem, affecting millions of people each year.

Aim: The present study was undertaken to study the profile of uropathogenic bacterial flora in adult, their antibiotic resistant pattern, adherence factors of uropathogens and in vitro adherence capabilities of Uropathogens.

Material and Methods: The samples were tested microbiologically by standard procedure. Antibiotic susceptibility of the isolated pathogens was tested for commonly used antibiotics by Kirby-Bauer technique according to CLSI guidelines. Adherence assay were done by hemagglutination test and Giemsa staining technique. Detection of hemolysin production was done on 5\% washed sheep blood agar. Motility test was done by stabbing the isolates into SIM biochemical media.

Results: Significant bacteriuria was present in $40 \%$ of samples. The most common pathogens isolated were Escherichia coli (52\%), followed by Klebsiella pneumoniae (16\%), Acinetobacter anitratus (11\%), Proteus mirabilis (6\%), Enterobacter species (5\%), Citrobacter species (2\%), Pseudomonas aeruginosa (2\%), Morganella morganii (1\%), Enterococcus species (3\%) and Staphylococcus aureus (2\%). The mean susceptibility of uropathogens was for amikacin (Ak-81\%), nitrofurantoin (Nf-60\%), cefotaxime (52\%), ceftriaxone (Ci-47\%), ciprofloxacin (Cf-45\%), norfloxacin (Nx-33\%), cotrimoxazole (Co-18\%) and nalidixic acid (Na-17\%). Mean adherence of pathogens to epithelial cells was 70 bacteria cell $^{-1}$. Of all, $52 \%$ isolates were hemagglutinating, $34 \%$ were alpha-hemolytic, $31 \%$ were beta-hemolytic and $68 \%$ were motile.

Conclusion: Escherichia coli are the commonest cause of UTI. Adherence is one of the essential pre-requisites to establish UTI. Majority of UTI in men are mono-microbial. Most of uropathogens are susceptible to amikacin (81\%) and nitrofurantoin $(60 \%)$.
\end{abstract}

Key words: UTI, uropathogens, adherence, antimicrobials.

\section{INTRODUCTION}

Urinary tract is the second most common site of bacterial infections in humans. ${ }^{1}$ The prevalence of Urinary tract infection (UTI) depends on age, sex, race and predisposing factors. ${ }^{2}$ Predisposing factors in the development of UTI are anatomical, physiological, infective, social and environmental. ${ }^{1,3}$ UTI occurs in any age and in sex. ${ }^{4}$ Mostly it is common in women than men. Female to male ratio is $4.6: 1 .^{5}$

Bacteria responsible for UTI, often originate from the faecal and perineal flora. ${ }^{6,7}$ UTIs are almost always caused by bacteria, although some viruses, fungi and parasites can infect the urinary tract as well. More than $85 \%$ of UTIs are caused by bacteria. Escherichia coli is the commonest cause of UTI followed by Klebsiella species, P. mirabilis, A. anitratus, Enterococcus faecalis, coagulase negative Staphylococcus, Streptococcus species. ${ }^{1,8,9}$

Under normal circumstances, these bacteria are cleared from the urinary system by effective protective mechanisms. If, however, they over come these mechanisms, subsequent progress is determined by host susceptibility and bacterial virulence factors. ${ }^{7}$ A significant factor for the pathogenesis of UTI is bacterial adhesion. ${ }^{10}$, ${ }^{11}$ Uropathogens achieve adherence to mucosal surface of urinary tract by fimbrial and non-fimbrial adhesions. ${ }^{9}$ According to hemagglutination (HA) patterns bacterial adhesions have been classified into two types, i.e., mannose sensitive hemagglutination (MSHA) and mannose resistant hemagglutination (MRHA). ${ }^{12}$
Bacteriological examination of the urine is the major aid to the diagnosis of infections. Culture technique is employed to detect bacteria in urine. ${ }^{13}$ The organisms are identified and their susceptibility to antimicrobial agents is determined. ${ }^{14}$ Adherence assay is done by HA test and Giemsa staining technique. ${ }^{15,16}$ Detection of hemolysin production is done on $5 \%$ washed sheep blood agar. ${ }^{17,18}$ Motility test is done by stabbing the isolates into SIM biochemical media. ${ }^{17}$

\section{MATERIALS AND METHODS}

This is prospective study conducted in Department of Microbiology, Yuvaraja's College (Autonomous), University of Mysore, Mysore, India; from December 2010 to November 2012. Urine specimens obtained from adult patients (above 18 years) attending to K.R. hospital and Mission Hospital Mysore, clinically diagnosed as UTI and submitted to Microbiology Department of Clinical Laboratory Service (CLS) for bacteriological culture and sensitivity constitute the subject for study. Informed consent was taken from each subject included in the study. For this study, the inclusion criteria were dysuria, fever due to UTI, frequency, painful micturation and exclusion criteria were malignancy, diabetes, tuberculosis, metabolic disorder, subject on antibiotic treatment, dialysis, HIV seropositive on ART and catheterized urine specimen.

Microscopic study was done for each specimen. The microscopic findings e.g., pus cells, erythrocytes, epithelial cells, casts and crystals were recorded. ${ }^{19,20}$ 
Urine culture of the un-centrifuged urine was done by semi-quantitative method using standard wire loop. Sterilized inoculation loop was dipped in urine pot at $90^{\circ}$, a loopful of urine holding $0.001 \mathrm{ml}$ was taken. It was inoculated on cystein lactose electrolytes deficient agar (CLED) media, 5\% sheep blood agar and MacConkey agar respectively. The inoculated plates were incubated aerobically in bacteriological incubator set at $37^{\circ} \mathrm{C}$ for 24 $48 \mathrm{~h}^{21,22}$ Identification was done on the basis of colony morphology, grams stain, catalase test, oxidase test and standard biochemical tests that include triple sugar iron agar (TSI) media, Simmons' citrate agar media, sulphide indole motility (SIM) media, and Christensens' urease medium.$^{23}$

\section{Antibiotic sensitivity test (AST)}

It was done by Kirby-Bauer disk diffusion test method on Muller-Hinton agar (MHA) plate and interpreted according to CLSI guidelines. Escherichia coli ATCC 25922 were used as control and tested along with the test strains daily as described for Enterobacteriaceae. ${ }^{14}$

\section{Adherence assay}

Adherence assay was done by HA test ${ }^{16,17,24}$ and Giemsa staining technique.

\section{A) Hemagglutination (HA) test}

It was done by Slide agglutination method and microtiter plate agglutination method.

\section{a) Slide agglutination method}

Eight glass slide $(3 \times 1$ inch) was taken and bacterial isolate number on each glass slide plus human $(\mathrm{H})$, sheep $(\mathrm{S})$, rabbit $(\mathrm{Rb})$, rat $(\mathrm{Ra})$ in first 4 slide respectively; similarly $\mathrm{H}+, \mathrm{S}+, \mathrm{Rb}+, \mathrm{Ra}+$ in next 4 slide respectively for red blood cell suspension with $1 \%$ mannose were marked. For each slide $50 \mu 1$ of PBS with $\mathrm{pH} 7.2$ was added; bacterial colony was taken from $5 \%$ sheep blood agar plate and emulsion was made on each glass slide. A total of $50 \mu \mathrm{l}$ of $4 \%$ red cell suspension with $1 \%$ mannose and without mannose of all 4 species was added on respective marked slide with bacterial milky white emulsion (approximately $1 \times 10^{9}$ bacteria $/ \mathrm{ml}$ ); then mixed with sterilized wooden tooth pick separately on each glass slide. The slide was rotated for 1 minute. ${ }^{16}$ Hemagglutination was observed, initially macroscopically and then microscopically using $10 \times$ objective and interpreted as $+1,+2,+3$ according to agglutination pattern. The results were recorded.

\section{b) Microtiter hemagglutination method}

With the help of sterilized inoculation loop, from bacterial stock vial subculture was done in BHI broth $(3-5 \mathrm{ml})$ and incubated aerobically for $4 \mathrm{~h}$ at $37^{\circ} \mathrm{C}$ in bacteriological incubator. ${ }^{1}$ Following incubation, subculture was done in $10 \mathrm{ml}$ Brain Heart Infusion (BHI) broth in McCartney bottle and incubated statically aerobically overnight at $37^{\circ} \mathrm{C}$ in bacteriological incubator. ${ }^{25}$ In test tube rack 16 clean, sterilized $(25 \mathrm{ml})$ test tubes were kept and marked 116 respectively. Each tube was filled with $9 \mathrm{ml} \mathrm{PBS;} \mathrm{pH}$ 7.2. Using $1 \mathrm{ml}$ delivering micropipette, the overnight bacterial broth in McCartney bottle was taken in and out 34 times, then $1 \mathrm{ml}$ broth was pipetted out, any excess drop was removed with tissue paper from outside of the tips. Carefully the broth in pipette was delivered into the tube number 1 , by touching the wall of tube but not dipping into the diluents. With fresh sterile tips, the first dilution was done by filling in and out 3-4 times, and then $1 \mathrm{ml}$ suspension was transferred to next tube (tube number 2). In the same way remaining dilutions were done. Surface viable count was done by Miles and Misra method. ${ }^{26}$ Using $20 \mathrm{ml}$ micropipette, from each tube $20 \mu \mathrm{l}$ suspension was allowed to fall from a height $2.5 \mathrm{~cm}$ on a well dried nutrient agar plate in duplicate, where it spreads over 1.5-2 $\mathrm{cm}$ in diameter.

The plates were incubated aerobically over night at $37^{\circ} \mathrm{C}$. Colony without confluence was counted and calculated bacteria per $\mathrm{ml}$ using formula: Bacteria per $\mathrm{ml}$ in BHI broth $=$ Number of colony $\times 50$. After that the broth culture was compared with McFarland 0.5 standards. The turbidity was adjusted by diluting with PBS pH 7.2. The tube containing $2 \times 10^{8}$ bacteria per $\mathrm{ml}$ in $\mathrm{PBS} \mathrm{pH} 7.2$ were used for HA test. ${ }^{27}$ A 96 well micro titer plate was taken. For 1 bacterial isolates 8 wells were selected, number isolated and marked M+ and M-. 100 micro liter 4\% red blood cells suspension of human, sheep, rabbit, and rat without mannose in PBS pH 7.2 and with $1 \%$ mannose in PBS pH 7.2 were added in respective well. Bacterial inoculum $(100 \mu \mathrm{l})$ was inoculated to BHI broth $\left(2 \times 10^{8}\right.$ bacteria $\mathrm{ml}^{-1}$ ) in each well and mixed by shaking for 1 minute. Well containing only the suspension of $4 \%$ erythrocytes were used as negative control. Using Parafilm, the micro titer plate was covered. A small pellet of erythrocytes at the bottom after 1 hour incubation at $37^{\circ} \mathrm{C}$ were considered negative, and those containing an even sheet of erythrocytes across the well were considered positive. ${ }^{27}$ Following incubation the first reading (HA) was recorded. Again applying parafilm microtiter plate was covered and kept in $4^{\circ} \mathrm{C}$ for overnight and second reading was recorded.

\section{B) Giemsa staining}

Adherence assay of uropathogenic bacteria was done on buccal epithelial cells by Giemsa staining as described by Foresteir et al. ${ }^{15}$ With certain modifications for selected uropathogenic clinical isolates. Detection of hemolysin production and motility testing were done by standard microbiological procedure. ${ }^{17}$

\section{RESULTS}

Out of 250 test urine specimen, $150(60 \%)$ were either insignificant growth or sterile and $100(40 \%)$ culture positive (significant bacteriuria), $98 \%$ were monomicrobial and $2 \%$ were polymicrobial (Table-1). The $100 \%$ of control specimen were either insignificant growth or sterile. Out of 102 isolates $95(93.13 \%)$ were gram negative bacteria and $7(6.87 \%)$ gram positive bacteria. (Table 1, $2 \& 3$ ). 
Table 1: Distribution of organisms isolated in UTI patients

\begin{tabular}{|c|c|c|c|}
\hline Bacteria & $\begin{array}{c}\text { IP* } \\
\mathbf{n}=\mathbf{1 2 5}(\%)\end{array}$ & $\begin{array}{c}\text { OPD } * * \\
\mathrm{n}=125(\%)\end{array}$ & $\begin{array}{c}\text { Total } \\
n=250\end{array}$ \\
\hline Escherichia coli & $30(48.4)$ & $22(55)$ & $52(51)$ \\
\hline Klebsiella pneumonia & $10(16.12)$ & $6(15)$ & $16(15.7)$ \\
\hline Acinetobacter anitratus & $6(9.7)$ & $5(12.5)$ & $11(10.8)$ \\
\hline Enterobacter species & $3(4.83)$ & $2(5)$ & $5(4.9)$ \\
\hline Proteus species & $3(4.83)$ & $3(7.5)$ & $6(5.9)$ \\
\hline Citrobacter species & $2(3.22)$ & -- & $2(1.96)$ \\
\hline Pseudomonas aeruginosa & $2(3.22)$ & -- & $2(1.96)$ \\
\hline Morganella morgani & $1(1.61)$ & -- & $1(1)$ \\
\hline Enterococcus species & $3(4.83)$ & $1(2.5)$ & $4(3.9)$ \\
\hline Staphylococcus aureus & $2(3.22)$ & $1(2.5)$ & $3(2.94)$ \\
\hline Total & $62(49.6 \%)$ & $40(32 \%)$ & $102(100 \%)$ \\
\hline
\end{tabular}

Table 2: Incidence of UTI in age group divided in 10 year interval

\begin{tabular}{|c|c|c|c|}
\hline Age (year) & Significant bacteriuria (\%) & Sterile (culture negative) (\%) & Total (\%) \\
\hline $18-27$ & $17(32)$ & $36(68)$ & $53(21.2)$ \\
\hline $28-37$ & $13(27)$ & $35(73)$ & $48(19.2)$ \\
\hline $38-47$ & $12(41.4)$ & $17(58.6)$ & $29(11.6)$ \\
\hline $48-57$ & $16(47)$ & $18(53)$ & $34(13.6)$ \\
\hline $58-67$ & $15(50)$ & $15(50)$ & $30(12)$ \\
\hline $68-77$ & $12(40)$ & $18(60)$ & $30(12)$ \\
\hline $78-87$ & $15(57.7)$ & $11(42.3)$ & $26(10.4)$ \\
\hline Total & $\mathbf{1 0 0}(\mathbf{4 0} \%)$ & $\mathbf{1 5 0}(\mathbf{6 0 \%})$ & $\mathbf{2 5 0}(\mathbf{1 0 0 \%})$ \\
\hline
\end{tabular}

Table 3: Antimicrobial resistance pattern

\begin{tabular}{|l|c|c|c|c|c|c|c|c|c|}
\hline \multicolumn{1}{|c|}{ Bacteria (No.) } & $\begin{array}{c}\mathbf{A} \\
(\boldsymbol{\%})\end{array}$ & $\begin{array}{c}\mathbf{A k} \\
(\boldsymbol{\%})\end{array}$ & $\begin{array}{c}\mathbf{C e} \\
(\boldsymbol{\%})\end{array}$ & $\begin{array}{c}\mathbf{C i} \\
(\boldsymbol{\%})\end{array}$ & $\begin{array}{c}\mathbf{C f} \\
(\boldsymbol{\%})\end{array}$ & $\begin{array}{c}\mathbf{C o} \\
(\boldsymbol{\%})\end{array}$ & $\begin{array}{c}\mathbf{N a} \\
(\boldsymbol{\%})\end{array}$ & $\begin{array}{c}\mathbf{N f} \\
(\boldsymbol{\%})\end{array}$ & $\begin{array}{c}\mathbf{N x} \\
(\boldsymbol{\%})\end{array}$ \\
\hline Escherichia coli $(\mathrm{n}=52)$ & 100 & 17.3 & 47 & 52 & 63.5 & 85 & 80.8 & 21.2 & 71.2 \\
\hline Klebsiella pneumoniae $(\mathrm{n}=16)$ & 100 & 12.5 & 75 & 75 & 75 & 93.7 & 87.5 & 68.7 & 75 \\
\hline Acinetobacter anitratus $(\mathrm{n}=11)$ & 100 & 18.2 & 27.3 & 27.3 & 18.2 & 81.8 & 81.8 & 72.7 & 45.5 \\
\hline Enterobacter species $(\mathrm{n}=5)$ & 100 & 60 & 80 & 100 & 40 & 60 & 100 & 60 & 80 \\
\hline Proteus mirabilis $(\mathrm{n}=6)$ & 100 & 0 & 0 & 33.3 & 50 & 66.7 & 100 & 0 & 50 \\
\hline Citrobacter species $(\mathrm{n}=2)$ & 100 & 50 & 100 & 100 & 50 & 100 & 100 & 100 & 100 \\
\hline Pseudomonas aeruginosa $(\mathrm{n}=2)$ & 100 & 50 & 100 & 100 & 50 & 100 & 100 & 50 & 100 \\
\hline Morganella morgani $(\mathrm{n}=1)$ & 100 & 0 & 0 & 0 & 0 & 100 & 0 & 0 & 0 \\
\hline Enterococcus species $(\mathrm{n}=4)$ & 100 & 0 & 0 & 0 & 0 & 25 & 100 & 100 & 25 \\
\hline Staphylococcus aureus $(\mathrm{n}=3)$ & 100 & 33.3 & 33.3 & 0 & 33.3 & 33.3 & 100 & 33.3 & 33.3 \\
\hline Total No. $(\mathrm{n}=\mathbf{1 0 2})$ & $\mathbf{1 0 0}$ & $\mathbf{1 9 . 6}$ & $\mathbf{4 7}$ & $\mathbf{5 2}$ & $\mathbf{5 4}$ & $\mathbf{8 0 . 4}$ & $\mathbf{8 2 . 4}$ & $\mathbf{4 0 . 2}$ & $\mathbf{6 5 . 7}$ \\
\hline
\end{tabular}

\section{Hemagglutination properties}

There are 23 different agglutination patterns in 52 hemagglutinating uropathogens. (Table-4, 5 \& 6) 
Table 4: Distribution of hemagglutination and non-hemagglutination properties of uropathogens isolated from patients with various forms of UTI

\begin{tabular}{|c|c|c|c|c|c|}
\hline Bacteria & $\begin{array}{l}\text { Total } \\
\text { No. }\end{array}$ & $\begin{array}{l}\text { Only MRHA } \\
\text { No. }(\%)\end{array}$ & $\begin{array}{l}\text { Only MSHA } \\
\text { No. }(\%)\end{array}$ & $\begin{array}{l}\text { Both MRHA and } \\
\text { MSHA No. }(\%)\end{array}$ & $\begin{array}{c}\text { Non-hemagglutination } \\
(\%)\end{array}$ \\
\hline Escherichia coli & 52 & $4(12.5)$ & $3(9.37)$ & $25(78.12)$ & $20(38.5)$ \\
\hline Klebsiella pneumonia & 16 & $1(14.28)$ & $4(57.14)$ & $2(28.57)$ & $9(46.25)$ \\
\hline Acinetobacter anitratus & 11 & $2(28.57)$ & $2(28.57)$ & $3(42.85)$ & $4(36.4)$ \\
\hline Enterobacter species & 5 & -- & $1(50)$ & $1(50)$ & $3(60)$ \\
\hline Proteus species & 6 & -- & $1(50)$ & $1(50)$ & $4(67.7)$ \\
\hline Citrobacter species & 2 & -- & -- & $1(100)$ & $1(50)$ \\
\hline $\begin{array}{l}\text { Pseudomonas } \\
\text { aeruginosa }\end{array}$ & 2 & -- & -- & $1(100)$ & $1(50)$ \\
\hline Morganella morgani & 1 & & & & $1(100)$ \\
\hline Total (\%) & 95 & 7 (13.46) & $11(21.11)$ & $34(65.38)$ & $43(45.27)$ \\
\hline
\end{tabular}

Table 5: Pattern of adherence to human buccal epithelial cells with hemagglutination property of uropathogens

\begin{tabular}{|l|c|c|c|}
\hline Bacteria & $\begin{array}{c}\text { Mean adhesion in } \\
\text { only MRHA }\end{array}$ & $\begin{array}{c}\text { Mean adhesion in } \\
\text { only MSHA }\end{array}$ & $\begin{array}{c}\text { Mean adhesion in } \\
\text { MRHA and MSHA }\end{array}$ \\
\hline Escherichia coli & 45 & 62 & 71 \\
\hline Klebsiella pneumonia & 40 & 54 & 60 \\
\hline Acinetobacter anitratus & 42 & 55 & 65 \\
\hline Enterobacter species & - & 50 & 55 \\
\hline Proteus species & - & 44 & 65 \\
\hline Citrobacter species & - & - & 54 \\
\hline Pseudomonas aeruginosa & - & - & 50 \\
\hline
\end{tabular}

Table 6: Distribution of hemolysin production by gram negative uropathogenic isolates

\begin{tabular}{|l|c|c|c|c|}
\hline \multicolumn{1}{|c|}{ Bacteria } & $\begin{array}{c}\text { Total } \\
\text { No. }\end{array}$ & $\begin{array}{c}\text { Alpha hemolysis } \\
(\mathbf{\%})\end{array}$ & $\begin{array}{c}\text { Beta hemolysis } \\
(\mathbf{\%})\end{array}$ & $\begin{array}{c}\text { Gamma hemolysis } \\
(\boldsymbol{\%})\end{array}$ \\
\hline Escherichia coli & 52 & $24(46.15)$ & $14(27)$ & $14(27)$ \\
\hline Klebsiella pneumonia & 16 & $4(25)$ & $3(18.75)$ & $9(56.25)$ \\
\hline Acinetobacter anitratus & 11 & $1(9)$ & $5(45.45)$ & $5(45.45)$ \\
\hline Enterobacter species & 5 & - & $2(40)$ & $3(60)$ \\
\hline Proteus species & 6 & $1(16.67)$ & $2(33.33)$ & $3(50)$ \\
\hline Citrobacter species & 2 & $1(50)$ & $1(50)$ & - \\
\hline Pseudomonas aeruginosa & 2 & - & $2(100)$ & - \\
\hline Morganella morgani & 1 & $1(100)$ & - & - \\
\hline Total & $\mathbf{9 5}$ & $\mathbf{3 2 ( 3 3 . 7 )}$ & $\mathbf{2 9 ( 3 0 . 5 )}$ & $\mathbf{3 4}(\mathbf{3 5 . 8})$ \\
\hline
\end{tabular}

\section{DISCUSSION}

In present study, E. coli was the most common organism isolated in $51 \%$ of patient. This finding is in between result of study by Raco et al. ${ }^{28}$ (1998) (49.37\%), Bonadio et al. ${ }^{29}$ (2001) (54.7\%), K. pneumoniae was the second most common organism isolated in $16 \%$ of patient. The similar result was seen in study by Das et al. (2006) $(15.7 \%)^{30}$ and Neto et al..$^{31}$ (2003) (15\%). Acinetobacter anitratus was the third most common organism isolated in $11 \%$ of patient. This result is higher than the other study. ${ }^{30,31}$ Proteus mirabilis was the fourth most common organism isolated in $6 \%$ of patient. The similar findings was studied by Villar et al. $^{32}$ (1996) (6\%) and Raco et al. ${ }^{28}$ (1998) $(8.86 \%)$. Pseudomonas aeruginosa was isolated $2 \%$ of patient. The similar finding was seen in study by Das et al. ${ }^{30}$ (2006) (2.9\%), 4 isolates of Enterococcus species 
Navin et al

Journal of Drug Delivery \& Therapeutics; 2013, 3(4), 93-98

$(3.9 \%)$ and $S$. aureus of $2.94 \%$. The similar finding was seen in study by Das et al. ${ }^{30}$ (2006) (3.4\%).

Significant bacteriuria was highest $57.7 \%$ in age group 7887 , followed by $50 \%$ in age group $58-67,47 \%$ in age group $48-57,41.4 \%$ in age group $38-47,40 \%$ in age group $68-77,32 \%$ in age group $18-27$ and $27 \%$ in age group $28-$ 37.The present results indicate that incidence of UTIs is more in older male patients. It might be due to prostate enlargement, because 42 patients included in present study were having $\mathrm{BPH}$ as an underlying condition. This result was supported by previous study. ${ }^{33}$

\section{Antimicrobial resistance}

The problem of bacterial antibiotic resistance emerged as soon as the first antibiotics became available for clinical use. Area-specific monitoring studies aimed to gain knowledge about the type of pathogens responsible for UTIs and their resistance patterns may help the clinician to choose the correct treatment. ${ }^{34}$ In present study, the antimicrobial resistance pattern of bacteria isolated from patients with UTI shows that $100 \%$ to ampicillin, $82.4 \%$ to nalidixic acid, $80.4 \%$ to cotrimoxazole, $65.7 \%$ to norfloxacin, $54 \%$ to ciprofloxacin, $52 \%$ to ceftriaxone, $47 \%$ to cefotaxime, $40.2 \%$ to nitrofurantoin and $19.6 \%$ to amikacin.

Most of isolated uropathogens showed multiple antibiotics resistance in this area. It may be due to large proportion of the bacterial isolate being previously exposed to several antibiotics. The present study data gives an idea about the common trend of increased antibiotics resistance of uropathogens in this region, which may be due to geographic variation or indiscriminate or sub lethal use of antibiotics. These results not only help in proper treatment of UTI patients but also discourage the indiscriminate use of antibiotics and prevent further development of bacterial drug resistance. This result will also help the clinicians to give proper treatment and prescription of most sensitive antibiotic to the patient and avoid use of resistant antibiotics.

\section{Hemagglutination properties}

In the present study, 95 gram negative uropathogenic bacteria have been tested for HA by using $4 \%$ RBCs suspension of human, sheep, rabbit and rat in absence and in presence of $1 \%$ mannose, 52 (54.73\%) were hemagglutinating and $43(45.27 \%)$ non-hemagglutinating. Escherichia coli and A. anitratus were maximum hemagglutinating $61.5 \%$ and $63.5 \%$ respectively, followed by Citrobacter species and $P$. aeruginosa $50 \%, K$. pneumoniae $43.7 \%$ and Enterobacter species $40 \%$. There were 23 different agglutination patterns in 52 hemagglutinating uropathogens. Thirty-seven (71.15\%) hemagglutinating bacteria were both MRHA and MSHA of different species of erythrocytes, 10 (19.23\%) were only MRHA of different species of erythrocytes and only 7 $(13.46 \%)$ were MSHA of different species of erythrocytes.

Fifty-two hemagglutinating gram negative uropathogenic bacteria have been tested for adherence to human buccal epithelial cells. Adherence was higher in gram negative uropathogenic bacteria which give both MSHA and MRHA, in comparison to only MRHA or MSHA respectively. Maximum adherence capability was seen in E. coli (71/ cell) giving both MSHA and MRHA, followed by $A$. anitratus and Proteus species (65/cell), $K$. pneumoniae (60/cell), Enterobacter species (55/cell) and $P$. aeruginosa (50/cell). Similarly adherence of uropathogens giving only MRHA, higher adherence capability was seen in $E$. coli (62/cell), followed by $A$. anitratus (55/cell), K. pneumoniae (54/cell), Enterobacter species (50/cell) and Proteus species (44/cell). There was no only MRHA in other uropathogens. Adherence of uropathogens giving only MSHA, higher adherence capability was seen in $E$. coli (45/cell), followed by $A$. anitratus (42/cell) and $K$. pneumoniae (40/cell). There was no only MSHA in other uropathogens.

The present results show that $E$. coli has higher adherence capability then other uropathogens, regardless of type of HA. The present study describes an in vitro model for the study of bacterial adhesion, using buccal epithelial cells of healthy individuals and uropathogens isolated from patients with UTI. The results confirm that adherence of microorganisms to uroepithelial cells is important for the establishment of infections of urinary tract. In present study 95 gram negative uropathogenic bacteria have been tested for hemolysin production; 32 (33.7\%) were $\alpha$ hemolytic, $29(30.5 \%)$ were $\beta$-hemolytic and 34 (35.8\%) were $\gamma$-hemolytic. The present results indicate that there is no significant correlation in the hemolytic properties in case of hemagglutinating and non-hemagglutinating gramnegative uropathogens.

\section{CONCLUSION}

Escherichia coli are the commonest cause of UTI. Adherence is one of the essential pre-requisites to establish UTI. Majority of UTI in men are mono-microbial. Most of uropathogens are susceptible to amikacin (81\%) and nitrofurantoin (60\%). Most of the Gram-negative bacteria showed hemagglutinating to both MRHA and MSHA of different species of erythrocytes. Maximum adherence capability was seen in E. coli (71/ cell) giving both MSHA and MRHA. 


\section{REFERENCES}

1. Dhakal B, Pokhrel BM, Ahnn J. Microscopic detection of urinary tract infection in Nepalese patients. J Microbiol 2002; 267-73.

2. Anderson GG, Dodson KW, Hooton TM. Intracellular bacterial communities of uropathogenic Escherichia coli in urinary tract pathogenesis. Trends Microbiol 2004; 12(9):424-30.

3. Hull RA, Rudy DC, Donovan WH, Wieser IE, Stewart C, Darouiche RO.Virulence properties of Escherichia coli 83972, a prototype strain associated with asymptomatic bacteriuria. Infect Immun 1999; 67(1):429-32.

4. Neto JAD, Martins ACP, Silva LDM, Tiraboshi RB, Domingos ALA. Community acquired urinary tract infection: etiology and bacterial susceptibility. Acta Ciruvgica Brasileira 2003; 18(5): 33-5.

5. Harber MJ, Asscher WA. Virulence of urinary pathogens. Kidney Int 1985; 28:717-21.

6. Aronson M, Medalia O, Schori L, Mirelman D, Sharon N, Ofek I. Prevention of colonization of the urinary tract of mice with Escherichia coli by methyl alpha-D-manno pyranoside. J Infect Dis 1979; 139(3):329-32.

7. Grude N, Tveten Y, Jenkins A, Kristiansen BE. Uncomplicated UTIs bacterial findings and efficacy of empirical antibacterial treatment. Scand J Primary Health Care 2005; 23:115-9.

8. Akram M, Sahid M, Khan AU. Etiology and antibiotic resistance patterns of community acquired urinary tract infections in JNMC Hospital Aligarh, India. Ann Clin Microbiol Antimicrob 2007; $6(4): 1-7$.

9. Tambekar DH, Dhanokar DV, Gulhane SR, Khandelwal VK, Dudhane MN. Antibacterial susceptibility of some urinary tract pathogens to commonly used antibiotics. Afr J Biotechnol 2006; 5(17):1562-5.

10. Leigh D, Smith GR, Easmen CSF. Urinary tract infections, Principles of Bacteriology, Virology and Immunology: Bacterial disease, London: Edward Arnold, Topley and Wilsons 1990; 3:198-213.

11. Polito M, Minardi D, Montanari MP, Varaldo PE. Adherence of gramnegative uropathogens to human uroepithelial cells. Eur Urol 1987; 13(1-2):74-8.

12. Hagberg L, Jodal U, Korhonen TK, Lidin-Janson G, Lindberg U, Svanborg EC. Adhesion, hemagglutination and virulence of Escherichia coli causing urinary tract infections. Infec Immun 1981: 564-70.

13. Ananthnarayan R, Panikar CKJ. Text Book of Microbiology. $6^{\text {th }}$ edi. Chennai: Orient Longman, 2000:254-5.

14. Clinical and laboratory standards institute (CLSI) performance standards for antimicrobial susceptibility testing. 2006: $16^{\text {th }}$ Informational Supplement. M100-S16. Clinical and Laboratory Standards Institute, Wayne, PA.

15. Foresteir C, Meyer M, Favre-Bonte S, Rich C, Malpuech G, Le Bouguenec C, Sirot J. Enteroadherent Escherichia coli and diarrhea in children: a prospective case control study. J Clin Microbiol 1996; 2897-903.

16. Yamamoto T, Fujita K, Yokota T. Adherence characteristics to human small intestinal mucosa of Escherichia coli isolated from patients with diarrhea or urinary tract infections. J Infect Dis 1990; 162(4):896-908

17. Green PC, Thoman VL. Hemagglutination of human type O erythrocytes, hemolysin production and serogrouping of Escherichia coli isolated from patients with acute pyelonephritis, cystitis and asymptomatic bacteriuria. Infect Immun 1981; 31(1):309-15.

18. Kimra N, Kozaki A, Sakaki T. Selective screening of enterohemorrhagic Escherichia coli depending on hemolysis on Beutins' washed sheep blood agar plates. Kansenshogaku Zasshi 1998; 72(3):223-30.

19. Godkar PB, Godkar DP. Text Book of Medical Laboratory Technology. $2^{\text {nd }}$ edi. Mumbai. Bhalani Publishing House 2003:900-1.

20. McBridge LJ. Microscopic examination of urine sediment: text book of urinalysis and body fluids. Philadelphia, Lippincott. 1998: 90-116.

21. Collee JG, Dugid JP, Frasar AG. Laboratory strategy in the diagnosis of infective syndromes. Collee JG, Dugid JP, Frasar AG, Marmion BP, Simmons A. Mackie and MicCarteny Practical Medical Microbiology. $14^{\text {th }}$ edi. London: Churchil, Livingstone Inc; 1996:53-94.

22. Leong AYS. Principles and Practice of Medical Laboratory Sciences. New York, Churchill Livingston. 1997: 2:35-8.

23. Collee JG, Miles SR, Watt B. Test for identification of bacteria. Collee JG, Marmion BP, Simmons A. Mackie and MicCarteny Practical Medical Microbiology. $14^{\text {th }}$ edi. London, Churchil Livingstone Inc; 1996:131-49.

24. Eden CS, Briksson B, Hanson LA. Adhesion of Escherichia coli to human uroepithelial cells in vitro. Infect Immun 1977; 18(3):767-74.

25.Chang RC, Bruce AW. The influence of growth media on the morphology and in vitro adherence characteristics of gramnegative urinary pathogens. J Urol 1983; 129(2):411-7.

26. Brown R. Poxton IR. Centrifuges colorimeter and bacterial count. Collee JG, Marmion BP, Simmons A. Mackie and MicCarteny Practical Medical Microbiology. $14^{\text {th }}$ edi. London, Churchil Livingstone Inc; 1996:845-52.

27. Braun G, Vidotto MC. Evaluation of adherence, hemagglutination and presence of gene codifying for virulence factors of Acinetobacter baumannii causing UTI. Memorias do Instuto Oswaldo Cruz Rio de Janerio 2004; 99(8):839-44.

28. Raco MO, Barez MYC. Profile of community-acquired urinary tract infections in Davao City. Philippines $\mathrm{J}$ Microbiol Infect Dis 1998; 27(2):62-6.

29. Bonadio M, Meini M, Spitaleri P, Gigli C.Current microbiological and clinical aspects of urinary tract infections. Eur Urol 2001; 40(4):439-44

30. Das RN, Chandrasekhar TS, Joshi HS, Gurung M, Shrestha N, Shivananda PG. Frequency and susceptibility profile of pathogens causing urinary tract infections at a tertiary care hospital in Western Nepal. Singapore Med J 2006; 47(4):281-5.

31. Neto JAD, Silva LDM, Martins ACP. Prevalence and bacterial susceptibility of hospital acquired urinary tract infection. Acta Ciruvgica Brasileira 2003; 18(5):36-8.

32. Villar J, Berruiti JEB, D.D. Sierra DD. Bacteriology and resistance in ambulatory urinary infections. Aten Primaria 1996; 18(6):315-17

33. Meer PD, Chow CK. Bacteriostatic and bactericidal actions of boric acid against bacteria and fungi commonly found in urine. J Clin Pathol 1990; 43(6):484-7.

34. Car J. Urinary tract infections in women: diagnosis and management in primary care. Br Med J 2006; 332:94-7. 